\title{
Opinions of Pre-service Classroom Teachers towards Laboratory Using in Science Instruction and Their Preferences towards Laboratory Approaches
}

\author{
Nagihan Yıldırım \\ Correspondence: Nagihan Yıldırım, Faculty of Education, Recep Tayyip Erdoğan University, Rize, 53200, Turkey
}

$\begin{array}{lc}\text { Received: January 15, } 2016 & \text { Accepted: February 14, } 2016 \quad \text { Online Published: February 23, } 2016 \\ \text { doi:10.11114/jets.v4i3.1304 } & \text { URL:http://dx.doi.org/10.11114/jets.v4i3.1304 }\end{array}$

\begin{abstract}
This study is a descriptive study that adopts relational screening model with the aim of determining pre-service classroom teachers' opinions about laboratory use in science teaching their preferences among laboratory approaches and identifying the reasons of the answers given by the pre-service teachers. The sample of the study is 236 pre-service classroom teachers. The data were collected through "Questionnaire to Determine Pre-service Teachers Opinions towards Laboratory Use" and "Teachers' perceptions on Laboratory Applications Scale". In order to determine the laboratory approach that the pre-service teachers adopt, the students worked in groups. Each group was expected to prepare a lesson plan to teach a science concept they chose in the laboratory. As a result of the findings, it was found that although pre-service classroom teachers have positive opinions about using laboratory in science instruction, they perceive themselves incompetent at effective use of laboratory, laboratory safety and effective use of time in laboratory.
\end{abstract}

Keywords: laboratory, laboratory approaches, pre-service classroom teachers

\section{Introduction}

Day after day the borders of knowledge have expanded with an increasing speed. Accordingly, the technology advanced from a basic structure like wheel to microchips that can be produced thinner than a hair thread. Within this process it is apparent that societies should educate individuals who research, inquire, interpret, have problem solving skills, and who are capable of creating innovations to make their society head off others instead of just letting them stay being as passive utilizes of scientific knowledge and technologies. Science education has an important part in education of such individuals it tries to explain reason and result relationships of the phenomena in our universe by means of continuous observations, research, inquiry and experimental attempts. During this process variety of scientific information is gathered and this knowledge can be used to devise innovative technologies that can be used to solve our problems and make our life easier. From this point of view, science is perceived as the fundamental source of accumulating scientific knowledge and technological advancements (Güngör, 2008).

In this context importance given to science and science education has increased in our country and in the world. Countries virtually get into a competition in funding this field as well. As a reflection of these efforts along with the other courses, primary and secondary school level science course curricula were reviewed in terms of aims, methods, techniques and assessment processes and they were tried to be changed to fit the requirements of the modern age (Ministry of National Education Turkey MoNET, 2013). From this point of view, it was underlined that students should also learn how to access information and how to use knowledge in daily life along with learning concepts, principals and generalizations, laws and theories of science (Laipply, 2004; Gençtürk and Türkmen, 2007; Bahadır, 2007; Camc1, 2008, Duban, 2008; Erdoğan, 2010; Ergul et al., 2011; Yıldırım, Kurt and Güneş, 2014; Yıldırım and Konur, 2014). In order to manage such education the following points have become pre-requirements; applications in science course should be in form of scientific study, courses should be conducted in a way to make students experience the same processes that scientists experienced, and classrooms should be converted into scientific study areas (Yaşar and Duban, 2009; Yıldırım and Güneş, 2012; Y1ldırım et al., 2014). When science course is structed with the mentioned concerns, it is important to arrange environment and using proper methods and techniques. Particularly, laboratory implementations should be prioritized and students should be rendered active (Gallagher, 1987; Tobin, 1990; Hofstein and Lunetta, 2004; Ayas, Çepni and Akdeniz, 1994; Çepni, Akdeniz and Ayas, 1994; Ekici, 2002; Başdaş, 2007; Akçöltekin, 2008; Doğan, 2008; Demirer, 2009; Erdoğan, 2010; Arı and Bayram, 2011). However, the literature review has shown that in laboratory applications conducted within science course students generally perform closed-ended experiments or they are given ready-made procedures and they reach results only by firmly following these procedures (Özdemir and Azar, 
2004; Böyük, Demir and Erol, 2010; Demir, Böyük and Koç, 2011; Sarı, 2011, Güneş, Şener, Topal Germi and Can, 2013). Apparently, in the approaches mentioned above, students do not effectively experience variety of entities that can help solution of problem such as; critical thinking, observing, developing hypotheses, interpreting, decision making etc, which does not coincide with the purposes of the intended science education.

Doğan (2008) presented an inquiry- based laboratory environment to pre-service biology teachers. In the study the participating pre-service teachers reported that; laboratory applications of biology field course is important only when the purposes fulfilled properly, they had not been satisfied with previous laboratory applications whose aims were not clear, they have found the laboratory environment they used to desire with the methods applied within this study and they have learnt better. In the study by Güneş et al., (2013) opinions of teachers and students were collected towards laboratory use in science and technology course. The results of the study showed that although there are laboratories in all schools, not enough laboratory activities are included in science and technology courses; half of the teachers and $60 \%$ of the students reported that not enough experiments have been done because of having insufficient materials; 37 of the students reported that teachers do not want to conduct experiments.

\subsection{The Significance of Study}

Science course curriculum, first put into practice in 2001/2002 educational year by the Ministry of National Education, Education Board, MoNET, EB, was reviewed and reoffered with the name of Primary School Science \& Technology Course Curriculum in 2004 (Ministry of National Education Turkey MoNET, 2005). As follow up of these alterations, with "Primary school and Education Law with Number 6287" legislated on 30/3/2012, compulsory education was extended to 12 years and substantial improvements were made on the curricula particularly on primary school curricula (MoNET, EB, 2013). Eight year uninterrupted education converted into gradual structure in a way to have 4 year in the first stage and 4 year in the second. In the year 2005, with 4+4+4 system the name of "Science and Technology" course changed as "Sciences" course and it was started to be offered in $3^{\text {rd }}$ grade level. The main aim of these renovations and alterations was to promote science literacy. Science literacy is generally defined as the collection of science related skills, dispositions, values, understanding and knowledge which are required to individuals' improvement of their research-inquiry, critical thinking, problem solving and decision making skills, their self-management of carrying lifelong learning and sustaining their sense of curiosity towards their environments and the world (Bybee, 1999; De Boer , 2000; Duban, 2010).

Sciences course is taught by classroom teachers escaladed the importance of their possessing certain competences and the importance of the courses at university which are capable of providing these competences (Bulunuz and Ergül, 2001). Classroom teachers are supposed to have sufficient field knowledge and competence in science field and related psychomotor behaviors (preparing laboratory order, using or preparing tools or materials). In addition they should know how to set learning environments to foster science instruction and they also should be able to use contemporary methods and techniques. There have been lots of studies conducted that investigate laboratory related competences of classroom teachers and pre-service teachers. Some of the findings of these studies can be summarized as below: Erdemir, Aydın and Soylu, (1999) reported that teachers rarely use materials in instruction. In their study Çepni, Küçük and Ayvac1, (2003) found that pre-service science teachers do not perceive themselves competent; they cannot perform laboratory practices at an intended level and they have field related misconceptions. Another study, on the other hand, disclosed that classroom teachers mostly teach lesson with classical methods and techniques rather than student-centered techniques (Dindar and Yaman, 2002). Similarly, other studies state that pre-service teachers have misconceptions over the concepts in science and technology course (Karaer, 2007; Konur and Ayas, 2008). The study by Küçükyılmaz and Duban, (2006) revealed that pre-service teachers at the beginning of their career bear worries that they fail to adjust their knowledge along with student level, to do experiments and to make students do experiments, to use special instructional methods and technologies. Another result of this study is that science and technology course is one of the courses that teachers have problems in instruction. Another of this study was teacher opinions suggesting that classroom teachers should only instruct $1^{\text {st }}, 2^{\text {nd }}$ and $3^{\text {rd }}$ grades. Güneş and Demir (2007) argued that science content of Life Science course in the first 4 year level is insufficient and it cannot prepare students to science course in the second level. Coştu et al., (2005) mentioned that pre-service teachers have weaknesses in laboratory use in sciences course and thus their knowledge and skills should be improved to an acceptable level. Tekin, Uluçınar, Sağır and Karamustafaoğlu, (2012) found that pre-service classroom teachers do not sufficiently recognize tools used to measure volume, mass and weight and they cannot use them. Similar results were reached by Harman (2012). Güneş et al., (2013) noted that majority of teachers do not use laboratories, they even skip experiments, which can simply be done by using daily life objects, and they particularly focus on solving multiple choice tests as preparation for national exams rather than laboratory using particularly at $8^{\text {th }}$ grade level. Toraman and Alc1 (2013) aimed at presenting opinions of science and technology teachers over Sciences course curriculum, which was altered with the new $4+4+4$ system. As a result of the investigation considering curriculum development factors the researchers determined that teachers evaluated the 
renewed sciences course curriculum as positive in terms of aims, content, process and assessment. In the study inquiring the opinions of classroom teachers about Sciences course curriculum which had just been instructed at $3^{\text {rd }}$ grade level, Yıldırım and Akgün (2015) indicated the problems that the teachers face as teachers' lack of information about laboratory use, absence of a guidebook and a workbook, material shortage and lack of consolidation activities. Based on the related literature review it can be asserted that in-service and pre-service classroom teachers, in general, possess not enough knowledge and competences towards science instruction.

Pre-service classroom teachers 'meaningful learning of science concepts and their capability of applying these concepts in daily life will contribute their effective teaching these concepts to their forthcoming students and make them love science. Indeed, students' love towards science, their enthusiasm towards learning science concepts; in short, their developing positive attitudes related to science strictly depend on positive and rich experiences they are faced in early ages. For this reason pre-service classroom teachers should possess sufficient knowledge and competences in the field. The present study aims to contribute pre-service classroom teachers' expression of their up-to-date competences and opinions about laboratory using in science instruction. It is expected that the results of the present study will pave a way to examinations and interpretations towards the applicability and success of the new sciences curriculum because the competences and opinions of pre-service classroom teachers about laboratories will provide clues about how they will perform in early periods of their professional life. Since teachers with positive opinions towards laboratories and teachers having sufficient knowledge over laboratory usage, safety, types of experiments and laboratory approaches will use these items in their instruction, science curriculum will reach targets.

\subsection{Problem of Research}

In this study, opinions of pre-service classroom teachers about laboratory usage, which is a prominent component of science teaching, and their preferences towards laboratory approaches, were investigated with their entitled reasons. Along with this aim the following inquiries were pursued:

- What are the opinions of pre-service classroom teachers about their own competences in laboratory usage in science teaching?

- Which experiment types and laboratory approaches do pre-service classroom teachers think to use when they start their career?

- What are the opinions of pre-service classroom teachers about laboratory use in science teaching?

\section{Method}

This study is a descriptive study that adopts relational screening model with the aim of determining pre-service classroom teachers' opinions about laboratory use in science teaching and their preferences among laboratory approaches and identifying the reasons of the answers given by the pre-service teachers.

\subsection{Sample of Research}

The sample of the study is 236 pre-service teachers who were enrolled in 3rd year of Elementary Education Department in Recep Tayyip Erdoğan University Faculty of Education. The pre-service teachers take Science Laboratory Applications I and II courses in their 2nd year and Science and Technology Instruction I and II courses in 3rd year. In the curricula of these courses both provided theoretical knowledge and practical applications presented about laboratory use in science teaching, experiment types, laboratory approaches. Since the practices of the present study were implemented in the second term of $3^{\text {rd }}$ year, the pre-service teachers had already taken these courses.

\subsection{Data Collecting Tools and Data Analysis}

In order to determine the pre-service teachers' opinions about their own competences related to laboratory using in science teaching 'Questionnaire to Determine Pre-service Teachers Opinions towards Laboratory Use' developed by the researcher. The survey was composed of 6 open ended questions. The items in the draft form of the survey were reevaluated under the opinions of experts ( 1 assessment expert and 2 chemistry field experts) for the content and face validity. After this finalized form applied, the responses given by the students were grouped and tabulated with sample expressions. In order to determine opinions of the pre-service teachers about laboratory use in science instruction 'Teachers' perceptions on Laboratory Applications Scale' by Feyzioğlu, Demirdağ, Akyıldız and Altun, (2012) used. The scale is composed of 20, five-choice Likert type items. In the first place, the scale was applied to 100 pre-service teachers registered to Classroom Teacher Education Department in the same university, who were out of the sample. With this application Cronbach alpha reliability coefficient of the scale was determined as 0,85 . While the data coming from the scale and survey, the frequency and percentile of each item was determined and tables, also including quotations from student expressions, were formed.

In order to determine the laboratory approach that the pre-service teachers adopt, the students were grouped in 3 or 4 members. Each group was expected to prepare a lesson plan to teach a science concept they would choose in laboratory. 
Totally, 53 lesson plans were prepared by the sample. These plans were coded as D1, D2, ... D53. Data was analyzed using document analysis. To ensure of the data the developed lesson plans were assessed by the researcher and also by another chemistry education expert and grouped with respect to experiment type, purpose and the time of application and structure of application. After the analysis, two distinct analyses of the researchers were unified and the groupings were ended by collective investigation of lesson plans which are not in the same category. Finally, tables were formed by determination of frequency and percentiles of experiment types and laboratory approaches they used in lesson plans.

\section{Results}

\subsection{Findings Coming from Questionnaire}

The data obtained from Questionnaire to Determine Pre-service Teachers Opinions towards Laboratory Use'.

In the first item of the survey the pre-service teachers were asked whether they feel themselves qualified in terms of laboratory safety. The frequency and sample responses of this item are presented in Table 1.

Table 1. Opinions of pre-service teachers about their own competency on laboratory safety and related frequencies.

\begin{tabular}{|c|c|c|}
\hline & Yes (f) & Sample responses from the pre-service teachers who answered the item as yes. \\
\hline \multirow{5}{*}{ 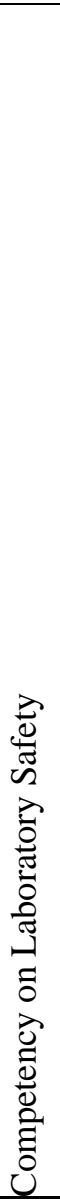 } & 36 & $\begin{array}{l}\text { - We did experiments in laboratory course in } 2^{\text {nd }} \text { year } \\
\text { - I feel myself confident in this issue; I make frequent repetitions and share my ideas with my } \\
\text { teachers. } \\
\text { - I think I can handle necessary safety precautions in laboratory. } \\
\text { - Because I previously plan experiment procedures and perform accordingly so I do not think there } \\
\text { would be any problem. } \\
\text { - Since the laboratory activities in primary school is at basic level and I have sufficient knowledge } \\
\text { level I think I am competent. }\end{array}$ \\
\hline & No(f) & Sample responses from the pre-service teachers who answered the item as no. \\
\hline & 32 & $\begin{array}{l}\text { - Since my teachers in my own primary school and secondary school times did not perform } \\
\text { laboratory activities, I do not feel myself competent. } \\
\text { - Because in my own education life I have only a few times been in laboratory. Simply I am not } \\
\text { accustomed to laboratory. There were only some superficial explanations about the laboratory } \\
\text { equipment, no application. } \\
\text { - Because it is only a one term lesson. Since we are not in laboratory continuously the knowledge } \\
\text { has faded away, we do not remember them clearly. } \\
\text { - Informing in this issue is not sufficient. } \\
\text { - There is no experience. } \\
\text { - I am afraid of flammables. } \\
\text { - I know the properties of the dangerous substances only by heart. } \\
\text { - I have only superficial knowledge about chemicals in laboratory. }\end{array}$ \\
\hline & Partly(f) & Sample responses from the pre-service teachers who answered the item as partly. \\
\hline & 108 & $\begin{array}{l}\text { - We have not used the laboratory very much at school. Although we havelearnt information about } \\
\text { laboratory using and safety; I find myself partly competent since I have no experience. } \\
\text { - It can be because I have had very little time in laboratory. In the course it is not taught which } \\
\text { substances are harmful and in which cases they should not be used. } \\
\text { - I do not find myself competent in terms of safety when explosives and harmful substances are } \\
\text { used. } \\
\text { - I remember as far as I see. } \\
\text { - We did not have enough opportunity to take our time with tools and materials in laboratory. The } \\
\text { excessive numbers of students make it harder for us to have in turn to deal with the equipment. } \\
\text { - I do not know much rather than basic level safety precautions. I can only manage low risk } \\
\text { experiments, which means I have problems with safety. }\end{array}$ \\
\hline & $\begin{array}{l}\text { No } \\
\text { explanations } \\
\text { (f) }\end{array}$ & - 60 students did not write any explanations to this item. \\
\hline
\end{tabular}

Thirty six students reported themselves as self-confident about laboratory safety, 32 students did not find themselves competent on laboratory safety and 108 of them thought that they are partly qualified in terms of laboratory safety (Table 1). 60 students did not response the item in any way. The students with the answer 'yes' mainly mentioned the benefits of 'Science Laboratory Applications' and 'Science and Technology Instruction' courses they completed in their $2^{\text {nd }}$ and $3^{\text {rd }}$ years. Some students gave responses like: 'Because I previously plan experiment procedures and perform accordingly so I do not think there would be any problem.', 'In laboratories, improper substances are placed out of reach of students', 'Since the laboratory activities in primary school is at basic level and I have sufficient knowledge I think I am competent.' The students answered the item as 'no' mentioned that the courses related to laboratory safety were not sufficient, their lack of experiences and their lack of knowledge about tools and materials in laboratories. One student disclosed that he is afraid of flammables. 
When the responses of the students with the answer 'partly' were examined, it was found that they generally mentioned that they have taken the laboratory related courses but they did not enough opportunities to practice.

The second item asked whether students feel themselves competent in effective use of laboratory. The corresponding answers were presented in Table 2.

Table 2. Opinions of pre-service teachers about their own competency on effective use of laboratory and related frequencies.

\begin{tabular}{|c|c|c|}
\hline & Yes(f) & Sample responses from the pre-service teachers who answered the item as yes. \\
\hline \multirow[b]{5}{*}{ 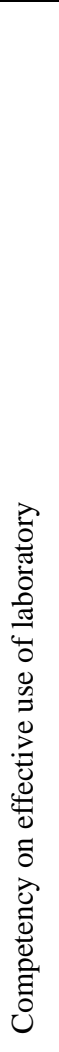 } & 36 & $\begin{array}{l}\text { - We have learnt related infrastructure and materials. } \\
\text { - I think I will instruct the course efficiently because of the courses we have taken. } \\
\text { - I find myself confident at effective use of laboratory } \\
\text { - Thanks to practice we have made and our teacher, I think I am competent. } \\
\text { - I think learning is more persistent when students make experiments themselves so I think I will } \\
\text { use laboratory as long as possible. } \\
\text { - I know how to use microscope in laboratory and I can differentiate substances with regards to } \\
\text { their danger classes. }\end{array}$ \\
\hline & No(f) & Sample responses from the pre-service teachers who answered the item as no. \\
\hline & 41 & $\begin{array}{l}\text { - We have not been exposed to learning by doing and living } \\
\text { - We have just worked with basic substances. } \\
\text { - Science courses instructed simply based on memorizing } \\
\text { - I have had little experience in laboratory } \\
\text { - I do not have knowledge and experience } \\
\text { - I have not done enough experiments. } \\
\text { - I do not know which tool or material is used for what purpose. }\end{array}$ \\
\hline & Partly (f) & Sample responses from the pre-service teachers who answered the item as partly. \\
\hline & 120 & $\begin{array}{l}\text { - We had the related course but we have not had practice opportunity. } \\
\text { - It was explained theoretically; not practically. } \\
\text { - Because I have only once made practice in laboratory medium and I could only use certain } \\
\text { materials. We have learnt the use of all substances and materials and their functions but we have } \\
\text { not had sufficient amount of effective practices } \\
\text { - That we have crowded classrooms prevented us to have such competence, actually this is not the } \\
\text { main reason that I do not use but it could have been better. } \\
\text { - In science laboratory course we have done lots of experiments and we have learnt for what and } \\
\text { how to use things. Since we have made mostly under the supervision of the instructor I am partly } \\
\text { competent despite the fact that we have observed. } \\
\text { - There is too little practice based courses through university education. } \\
\text { - For a student studying just to achieve the exams about laboratory use learning cannot be } \\
\text { persistent. Eventually he does not feel himself competent when he is in the last school year. }\end{array}$ \\
\hline & $\begin{array}{l}\text { No } \\
\text { Explanations } \\
\text { (f) }\end{array}$ & 39 students did not write any explanations to this item. \\
\hline
\end{tabular}

Table 2 indicates that majority of the pre-service teachers feel themselves partly competent in effective laboratory use. When the responses thoroughly scrutinized they generally mentioned lack of practice, inability to effectively utilize and experience laboratory sessions because of crowded classrooms, lack of knowledge and experience and not having enough experiment experience.

Third item in the survey was inquiring whether pre-service teachers feel themselves competent in time-management in laboratory. The related responses are presented in Table 3. 
Table 3. Opinions of pre-service teachers about their own competency on time management in laboratory and related frequencies.

\begin{tabular}{|c|c|c|}
\hline & Yes (f) & Sample responses from the pre-service teachers who answered the item as yes. \\
\hline \multirow{6}{*}{$\begin{array}{l}\text { Competency on } \\
\text { time } \\
\text { management in } \\
\text { laboratory }\end{array}$} & 35 & $\begin{array}{l}\text { - I like laboratory and I believe I will use it effectively. } \\
\text { - I think I will particularly be good at determining student levels and so I will be able to } \\
\text { timely allocate my instruction. } \\
\text { - Because I will surely rehearse the experiment before I apply in classroom so I will face } \\
\text { no loss of time } \\
\text { - Yes, I feel competent because the education that I have had makes me more or less use } \\
\text { lesson time effectively and sensibly. } \\
\text { - Because I think I can manage time with a good lesson plan. } \\
\text { - Because if necessary adjustments are made with correct materials and substances, } \\
\text { experiment ends timely. }\end{array}$ \\
\hline & No (f) & Sample responses from the pre-service teachers who answered the item as no. \\
\hline & 43 & $\begin{array}{l}\text { - Because I have had no experience. } \\
\text { - Because I have had no experience of instruction by using laboratory. I had only one try } \\
\text { and I failed. } \\
\text { - All the experiments we have made so far were performed by instructors and there have } \\
\text { been only a few experiments on which we were active. } \\
\text { - I do not know how to work in a laboratory. } \\
\text { - Because I do not spend much time in laboratory } \\
\text { - For this aim I should often go to laboratory and I should be accustomed to it. }\end{array}$ \\
\hline & Partly (f) & Sample responses from the pre-service teachers who answered the item as partly. \\
\hline & 91 & $\begin{array}{l}\text { - When I do experiment I do not realize how time passes and generally I run out of time. } \\
\text { - Activities will be time consuming and some students will not be able to do experiments } \\
\text { in one time, they will have to repeat it. They will all waste time. But my students will learn } \\
\text { persistently and correct } \\
\text { - Because if I do an experiment with my students I will have to save more time and dealing } \\
\text { with students who do not understand may cause some time problems. } \\
\text { - It depends on number of students. } \\
\text { - I have some hesitations. Because as far as I observe in my school practices lesson does } \\
\text { not continue in the planned way, sometimes there may be unexpected situations. } \\
\text { - I have not had the opportunity to experience it much. } \\
\text { - It depends on students' speed of doing experiment and their perception. } \\
\text { - I prefer managing time effectively by focusing on applicable experiments. }\end{array}$ \\
\hline & $\begin{array}{l}\text { No } \\
\text { Explanations } \\
\text { (f) }\end{array}$ & 67 students did not write any explanations to this item. \\
\hline
\end{tabular}

It is obvious from Table 3 that most of the pre-service teachers perceive themselves partly competent in terms of effective management of time. In order to explain this situation the pre-service teachers mentioned following reasons; laboratory activities are time consuming, there are individual differences among students, classrooms are crowded and they have lack of experience.

In the fourth item in the survey the pre-service teachers were asked about with which purposes they plan to use laboratory in their instruction when they start their career. The corresponding responses were presented in Table 4. 
Table 4. Opinions of pre-service teachers about with which purposes they plan to use laboratory in their instruction.

\begin{tabular}{|c|c|}
\hline Pre-service teachers' aims of using laboratory in instruction & Sample student responses \\
\hline $\begin{array}{l}\text { - } \quad \text { Consolidating concepts taught in instruction } \\
\text { - } \quad \text { Attracting attention at the beginning of class hour } \\
\text { - } \quad \text { Associating concepts with daily life } \\
\text { - } \quad \text { Improving critical thinking } \\
\text { - } \quad \text { Visual usage in science courses } \\
\text { - } \quad \text { Sumcept teaching } \\
\text { - } \quad \text { Aaking lesson more attractive } \\
\text { - } \quad \text { Facilititating cooperative learning } \\
\text { - Educating researcher individuals with curiosity } \\
\text { - Improving cognitive and psychomotor skills of students } \\
\text { - } \quad \text { Providing students with scientific research process skills } \\
\text { Improving student self-esteem. }\end{array}$ & $\begin{array}{l}\text { - With the aim of consolidating instruction. } \\
\text { - In order to make students learning with visual } \\
\text { intelligence more effective } \\
\text { - To attract attention in the entrance stage } \\
\text { - To foster persistent learning in science courses and to } \\
\text { make instruction more attractive. } \\
\text { - Just for making experiments and stimulating students' } \\
\text { interest in science } \\
\text { - I plan to use it to concretize abstract concepts. Since } \\
\text { many students possess different skills and } \\
\text { intelligences, I will use laboratory to appeal more } \\
\text { sense organs. } \\
\text { - To make students like laboratory lesson to improve } \\
\text { their sense of trust by doing experiments, to improve } \\
\text { scientific research skills. Last but not least I will use } \\
\text { laboratory in order to contribute training science } \\
\text { people. } \\
\text {-I use to make theoretical knowledge more persistent } \\
\text { and to cheer } \quad \text { up } \\
\text { lesson........................................ }\end{array}$ \\
\hline
\end{tabular}

The pre-service teachers noted that when they start their teaching career they plan to use laboratory in their instruction for the following purposes: to consolidate concepts instructed in lesson, to attract attention in the entrance stage of lesson, to manage persistent learning, to associate concepts with daily life, to concretize abstract concepts, to improve student critical thinking skills, to improve scientific process skills and to summarize lesson etc.

In the fifth item in the survey the pre-service teachers were asked which type of experiments they plan to use most frequently when they start their teaching career and why they prefer that type. The responses were tabulated in Table 5 .

Table 5. Opinions of the pre-service teachers on which type of experiments they plan to use most frequently when they start their teaching career and related frequencies.

\begin{tabular}{|c|c|c|}
\hline Type of experiment & Frequency (f) & Sample reasons for answer \\
\hline Closed ended & 24 & $\begin{array}{l}\text { I will use demonstration and proof experiments. I will not frequently prefer hypothesis } \\
\text { experiments since they can be difficult for primary school students. } \\
\text { - I think I can manage better than the other types. } \\
\text { I suppose closed ended experiments are more suitable, I do not think that open ended } \\
\text { experiments are suitable for the level of pupils. } \\
\text { Since pupils will be young learners, I will not use open ended experiments not to cause } \\
\text { confusion. } \\
\text { Because the others can be risky } \\
\text { Open ended experiments will not be suitable for primary school pupils. Closed ended } \\
\text { experiments at least trigger awareness. } \\
\text { Because I think I can do this easily }\end{array}$ \\
\hline Open ended & 53 & $\begin{array}{l}\text { - In general, I will often use experiments with no pre-determined results, which attract } \\
\text { students' attention because experiments with defined results can be boring for students. } \\
\text { - I will make students ready for learning by making them wonder. Then we will do the } \\
\text { experiment altogether and manage learning by doing and living. } \\
\text { - In order to make students reach results without knowing them. } \\
\text { Because I will direct students to think. } \\
\text { It both arise wonder and facilitate learning since it goes from part to whole. } \\
\text { I will use open ended to make students equipped with scientific process skills and critical } \\
\text { thinking skills } \\
\text { Learning will be more persistent because students will be more active. } \\
\text { knowledge by themselves and knowledge will be their own. } \\
\text { With open ended experiments learning will be more persistent since students reach } \\
\text { students have no contribution to process, students perform an existing procedure, do not } \\
\text { discourse their thoughts. }\end{array}$ \\
\hline Hypothesis testing & 4 & $\begin{array}{l}\text { Because this make students actively participate the process. } \\
\text { Students learn better what they are curious about. } \\
\text { Students are more active; they set experiment mechanism, do experiments, find materials } \\
\text { themselves, and verify their hypotheses depending on experiment results. } \\
\text { Higher order skills of students improve. }\end{array}$ \\
\hline $\begin{array}{l}\text { Closed ended }- \text { open } \\
\text { ended }\end{array}$ & 6 & $\begin{array}{l}\text { - I will use open ended and closed ended depending on class level. } \\
\text { - I will use open ended experiment when I would like to arise pre-curiosity. If I want to } \\
\text { consolidate a unit, I will use closed ended experiments. } \\
\text { - Sometimes, I will use closed ended and sometimes I use open ended. }\end{array}$ \\
\hline No response & 129 & $\bullet$ \\
\hline
\end{tabular}


According to Table 5, 53 pre-service teachers preferred open ended experiments, 24 of them preferred closed ended experiments, 4 of them preferred hypothesis testing and 6 of them preferred open and closed ended experiments. 129 pre-service teachers left this item empty.

In sixth item the pre-service teachers were asked about which laboratory approach, they think, they will mainly use when they start teaching profession and what the reasons for this preference are. The related answers were presented in Table 6 .

Table 6. Opinions of the pre-service teachers about which laboratory approach, they think, they will mainly use when they start teaching profession and their frequencies

\begin{tabular}{lrlll}
\hline & & & Frequency (f) & Sample student responses \\
\hline $\begin{array}{l}\text { Approaches } \\
\text { provide }\end{array}$ & $\begin{array}{r}\text { which } \\
\text { necessary }\end{array}$ & $\begin{array}{l}\text { Approach for } \\
\text { for } \\
\text { performing } \\
\text { experiments }\end{array}$ & $\begin{array}{l}\text { foroving technical } \\
\text { skills }\end{array}$ & No explanations \\
\cline { 2 - 5 } & & $\begin{array}{l}\text { Approach based on } \\
\text { improving scientific } \\
\text { process skills }\end{array}$ & No explanations \\
\hline $\begin{array}{l}\text { Approach } \\
\text { conducting laboratory } \\
\text { activities }\end{array}$ & Verification approach 2 & - Students verify what they have learnt \\
\hline
\end{tabular}
activities

Induction approach 7
general information.

- Reaching the truth by assembling parts is more persistent.

Discovery approach $\quad 14$

- Reach knowledge by themselves, improve their critical thinking skills, communication with group mates gets better.

- Students should try and they should be directed to research.

- Encouraging children towards reasoning and researching, managing active participation, improving sense of curiosity.

- Since students are active, learning will be more persistent.

- So that students can reach scientific knowledge with experimental methods

Constructivist $19 \quad$ Since it is ask, think, produce, and solve approach.

learning based on

- Because it is more up-to-date

laboratory approach

- I use because students talk and express themselves better.

- I do not have much information about the others.

- Since it also include other laboratory approaches and provides more persistent learning.

- Since it makes students more active and it is quite comprehensive

- Since it includes learning by doing and living, in which students are active.

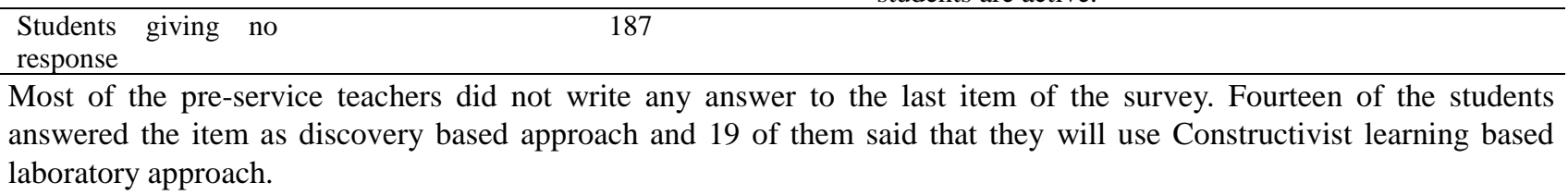

\subsection{Findings coming from Perceptions on Laboratory Applications Scale}

The percentiles of the responses by pre-service teachers to Perceptions on Laboratory Applications Scale are presented in Table 7. 
Table 7. Responses by pre-service teachers to perceptions on laboratory applications scale and response percentiles.

\begin{tabular}{|c|c|c|c|c|c|}
\hline Items & $\begin{array}{l}\text { Strongly } \\
\text { agree }\end{array}$ & Agree & $\begin{array}{l}\text { Neither agree } \\
\text { nor disagree }\end{array}$ & Disagree & $\begin{array}{l}\text { Strongly } \\
\text { disagree }\end{array}$ \\
\hline $\begin{array}{l}\text { 1. Laboratory applications increase the workload of } \\
\text { teachers. }\end{array}$ & 12 & 27,4 & 12,6 & 34,3 & 13,7 \\
\hline $\begin{array}{l}\text { 2. Laboratory applications limit the time that is spent } \\
\text { for science course. }\end{array}$ & 2,8 & 9,0 & 7,9 & 50,8 & 29,4 \\
\hline $\begin{array}{l}\text { 3. Laboratory applications are not didactic for } \\
\text { learners }\end{array}$ & 7,4 & 3,4 & 2,8 & 23,9 & 62,5 \\
\hline 4. Experiments improve learning skills of learners. & 72,1 & 23,3 & 6 & 2,9 & 1,2 \\
\hline $\begin{array}{l}\text { 5. Experiments equip learners with problem solving } \\
\text { skills. }\end{array}$ & 72,0 & 24,6 & 1,1 & 1,1 & 1,1 \\
\hline $\begin{array}{l}\text { 6. Learners consolidate knowledge that they have } \\
\text { learned in lesson in laboratory. }\end{array}$ & 74,0 & 22,0 & 1,1 & ,6 & 2,3 \\
\hline $\begin{array}{l}\text { 7. Experiments facilitate learners to make } \\
\text { associations with real life. }\end{array}$ & 63,1 & 32,4 & 2,3 & 1,1 & 1,1 \\
\hline $\begin{array}{l}\text { 8. Laboratory applications appeal to more than one } \\
\text { sense of learners. }\end{array}$ & 71,8 & 22,0 & 2,8 & 1,1 & 2,3 \\
\hline $\begin{array}{l}\text { 9. Experiments done in laboratory concretize abstract } \\
\text { concepts. }\end{array}$ & 67,0 & 27,3 & 3,4 & 6 & 1,7 \\
\hline $\begin{array}{l}\text { 10. Experiments improve critical thinking skills of } \\
\text { learners. }\end{array}$ & 63,8 & 31,1 & 2,3 & 1,7 & 1,1 \\
\hline $\begin{array}{l}\text { 11. Experiments done in laboratory help learners to } \\
\text { associate relations among concepts. }\end{array}$ & 59,3 & 32,8 & 5,1 & 1,1 & 1,7 \\
\hline $\begin{array}{l}\text { 12. Within cooperative learning environment in } \\
\text { laboratory learners can comfortably express } \\
\text { themselves in group. }\end{array}$ & 53,7 & 31,6 & 9,0 & 2,8 & 2,8 \\
\hline 13. Laboratory work is all waste of time & 4,6 & 4,6 & 4,0 & 37,1 & 49,1 \\
\hline $\begin{array}{l}\text { 14. Laboratory experiments increase persistence of } \\
\text { learning. }\end{array}$ & 68,0 & 22,7 & 1,2 & 1,7 & 6,4 \\
\hline 15. Laboratory works decreases efficiency of lesson. & 4,6 & 5,1 & 6 & 29,7 & 60,0 \\
\hline $\begin{array}{l}\text { 16. We can reach success by solving multiple choice } \\
\text { tests rather than wasting time in laboratories. }\end{array}$ & 4,0 & 3,4 & 5,1 & 24,0 & 63,4 \\
\hline $\begin{array}{l}\text { 17. Laboratory works make me stay behind } \\
\text { determined curriculum. }\end{array}$ & 2,9 & 8,7 & 19,1 & 31,2 & 38,2 \\
\hline 18. Laboratory works ruin classroom discipline. & 1,7 & 8,5 & 13,1 & 37,5 & 39,2 \\
\hline 19. Laboratory works reduce success of learners. & 2,3 & 4,0 & 1,1 & 31,6 & 60,3 \\
\hline $\begin{array}{l}\text { 20. Laboratory works help learners to discover } \\
\text { connections among science and other courses. }\end{array}$ & 46,3 & 41,7 & 5,7 & 3,4 & 2,9 \\
\hline
\end{tabular}

Table 7 presents that-\%12 - \%27,4of pre-service teachers had the opinion laboratory works increases the workload of teachers. \%50- \%74 of them, on the other hand, think that; experiments improve learning skills of learners, provide problem solving skills, help students associate connections with real life, improve critical thinking skills and foster persistent learning.

\subsection{Findings Coming from Lesson Plans}

Pre-service teachers prepared 53 lesson plans. Adopted approach and experiment types (with respect to aim of performing such an experiment, structure and frequencies) were presented in Table 8 together with related frequencies. 
Table 8. Laboratory approaches and experiment types in lesson plan and related frequencies

\begin{tabular}{|c|c|c|}
\hline Laboratory approaches & Lesson plans & $\begin{array}{l}\text { Frequency } \\
\text { (f) }\end{array}$ \\
\hline \multicolumn{3}{|l|}{$\begin{array}{l}\text { - Approaches for } \text { conducting } \\
\text { laboratory applications. }\end{array}$} \\
\hline 1. Deduction & D21 D28 D38 D46 & 4 \\
\hline \multicolumn{3}{|l|}{ 2. Induction } \\
\hline a. Discovery based approach & D1 D3 D5 D6 D7 D8 D9 D10 D11 D12 D15 D16 D17 D18 & 31 \\
\hline b. Research based approach & D19 D20 D24 D25 D31 D32 D33 D39 D42 D43 D45 D47 D48 & \\
\hline \multirow[t]{2}{*}{ c. Constructivism based approach } & D49 D50 D51 D53 & \\
\hline & $\begin{array}{l}\text { D2 D4 D13 D14 D22 D23 D26 D27 D29 D30 D34 D35 D36 } \\
\text { D37 D40 D41 D44 D52 }\end{array}$ & 18 \\
\hline \multicolumn{3}{|l|}{$\begin{array}{l}\text { - Approaches for providing skills } \\
\text { which are necessary for performing } \\
\text { experiments. }\end{array}$} \\
\hline 1. Improving technical skills oriented study. & D1 D47 & 2 \\
\hline $\begin{array}{l}\text { 2. Approach based on improving Scientific } \\
\text { Process skills }\end{array}$ & D1 D3 & 2 \\
\hline \multicolumn{3}{|l|}{ Types of experiment } \\
\hline \multicolumn{3}{|l|}{ - With respect to performing manner. } \\
\hline 1. Demonstration experiment. & D2 D4 D7 D10 D16 D19 D48D29 & 7 \\
\hline 2. Individual experiments & D5 D8 D13 D22 & 4 \\
\hline 3. Group experiments & $\begin{array}{l}\text { D1 D3 D6 D9 D11 D12 D14 D15 D17 D18 D20 D21 D23 D24 } \\
\text { D25 D26 D27 D28 D30 D31 D32 D33 D34 D35 D36 D37 } \\
\text { D38D39 D40 D41 D42 D43 D44D45 D46 D47 D49 D50 D51 } \\
\text { D52 D53 }\end{array}$ & 41 \\
\hline \multicolumn{3}{|l|}{ - With respect to aim } \\
\hline 1. Closed ended experiments & D21 D28 D38 D46 & 4 \\
\hline 2. Open ended experiments & $\begin{array}{l}\text { D1 D2 D3 D4 D5 D6 D7 D8 D9 D10 D11 D12 D13 D14 D15 } \\
\text { D16 D17 D18 D19 D20 D22 D23 D24 D25 D26D27 D29 D30 } \\
\text { D31 D32 D33 D34 D35 D36 D37 D39 D40 D41 D42 D43 D44 } \\
\text { D45 D47 D48 D49 D50 D51 D52 D53 }\end{array}$ & 49 \\
\hline \multicolumn{3}{|l|}{ 3. Hypothesis testing experiments } \\
\hline \multicolumn{3}{|l|}{ - With respect to time of application } \\
\hline 1. Pre-instruction experiments & D1 D15 & 2 \\
\hline 2. Experiments done during instruction & $\begin{array}{l}\text { D2D3 D4 D5 D6 D7 D8 D9 D10 D11 D12 D13 D14 D16 D17 } \\
\text { D18 D19 D20 D22 D23 D24 D25 D26 D27 D29 D30 D31 D32 } \\
\text { D33 D34 D35 D36 D37D38 D39 D40 D41 D42 D43 D44 D45 } \\
\text { D47D48 D49 D50 D51 D52 D53 }\end{array}$ & 48 \\
\hline 3. Post-instruction experiments. & D21 D28 D46 & 3 \\
\hline
\end{tabular}

As presented in Table 8 pre-service teachers developed activities mostly with induction approach. When it comes to experiment types they prefer open ended, group experiments and experiments done during instruction.

\section{Discussion}

Laboratory is defined as a medium where topic or concept of concern is presented to students artificially through experiences and demonstration (Akgün, 2008, Ayas et al., 1994).In primary school laboratories there are simpler material and tools complying with the attainments of primary school curriculum. For the efficiency of these studies, it is very important for students working in laboratories to know basic concepts and instructions such as; laboratory safety, laboratory rules, materials and tools and the way they are used (Akgün, 2008). Teachers who target to make students gain these behaviors should have these knowledge and competence themselves in the first place. First two items of the survey applied to pre-service teachers were asking whether they feel themselves confident at laboratory safety and effective use of laboratory. When Table 1 is reconsidered, 36 of pre-service teachers responded laboratory safety question as yes, 32 of them as no and 108 of them answered as partly. Sixty pre-service teachers did not answer this question. Those who positively answer the question mentioned the benefits of Science Laboratory Applications course and Science and Technology Instruction I and II courses which they have taken in their second and third year. While those who said 'no' highlighted inadequacy of related courses, their lack of experience and that they do not recognize chemicals and tools in laboratory. Finally, those who answered the question as 'partly' mainly reported that they had the laboratory related courses but they had not enough opportunities to apply what they have learnt and that they have lack of experiences.

However considering possible adverse effects of chemicals and chemical reactions on human health, laboratory safety is 
extremely important. Therefore teachers who are responsible for all possible actions of students in laboratory should have sufficient knowledge and competence. The present study has determined that pre-service teachers have not felt themselves sufficient in this issue. There have been similar results in the literature (Coştu et al., 2005; Tekin et al., 2012; Harman, 2012). Some of the pre-service teachers in the present study noted that they are afraid of laboratory accidents.

Table 2 indicates that most of the pre-service teachers feel themselves partly competent at effective use of laboratory. When their answers were examined in detail, as it is in first item, they put forward reasons like lack of application, cannot effectively utilize laboratory sessions because of crowded classrooms, lack of knowledge and experience and not doing adequate number of experiments. Based on opinions of the pre-service teachers it can be argued that although the courses towards laboratory applications are offered in pre-service period, pre-service teachers have not much application opportunity in laboratories. For these reasons majority of pre-service teachers do not feel themselves confident and competent at laboratory safety and effective use of laboratory. Similarly, Meriç and Ersoy (2007) and Küçükyılmaz and Duban (2006)'s study showed that pre-service teachers thought that the things they had learnt in Science Teaching I and II were partly sufficient, they thought they should have given more application opportunities and they noted that the course should have been mainly experience based. We think, this result repeated by different studies is worth considering in terms of the quality and improvement of teacher training.

In the third item the pre-service teachers were asked whether they feel themselves competent at time management in laboratory. When Table 3 is examined, it is observed that most of the pre-service teachers feel themselves partly competent at time management in laboratory. In order to explain their ambiguous state pre-service teachers indicated the following reasons: laboratory activities are time consuming, individual differences among students, crowded classrooms, and their own lack of experience.

In the fourth item asking pre-service teachers with which purposes they will use laboratory when they start teaching profession they expressed that they will use laboratory for: consolidating subject matter, attracting attention at the beginning of instruction, facilitating persistent learning, associating concepts with daily life, concretizing abstract concepts, improving critical thinking skills, improving scientific process skills, summarizing lesson etc. Following that, the pre-service teachers were asked which type of experiments mostly they plan to use when they start service. Table 5 illustrates 53 of pre-service teachers preferred open ended experiments, 24 of them preferred closed ended experiments, 4 of them hypothesis testing and 6 of them open and closed ended experiments. 129 of the pre-service teachers gave no response to this item. Afterwards, the pre-service teachers were asked which laboratory approach they plan to use when they start their profession. One hundred and eighty seven of the pre-service teachers gave no answer to this question. 7 of those who answered preferred induction, 14 of them discovery approach and 19 of them preferred constructivist learning theory based laboratory approaches.

Pre-service teachers who did not answer this question showed that they did not have appropriate knowledge over experiment types and laboratory approaches. However, primary school age, the age period between 6 and 14, is when pupils are most curious about science (Gürdal, 1992). In this age, questions of children are mostly about science topics. Directing this curiosity in a right and an efficient way is only possible with teaching science courses by learning by doing and experimenting it in a laboratory environment. The inadequacy of pre-service teachers will eventually adversely affect the education of students. There have been great number of studies stating that pre-service and in-service classroom teachers feel themselves incompetent at science content knowledge and pedagogical knowledge (Dindar and Yaman, 2002; Çepni, Küçük and Ayvac1, 2003; Coştu et al., 2005; Küçükyılmaz and Duban 2006; Güneş and Demir , 2007; Tekin et al., 2012; Güneş et al., 2013). In addition, Gömleksiz, Ülkü Kan and Biçer, (2010) reported that classroom teachers find themselves competent at teaching science and technology course but they sometimes have difficulties and they think certain courses should be taught by branch (field) teachers.

In the final stage of the study the pre-service teachers were grouped in groups of 3 or 4 members. Each group was expected to prepare a lesson plan to teach a science concept they would choose in the laboratory. When the plans were analyzed it was found out that 49 of them were planned based on open ended experiments and 4 of them were based on closed ended experiment. Laboratory work contributes not only to certain cognitive skills of students like reasoning, critical thinking and understanding science, but also to affective skills like voluntarily participate to science course by self-experiencing the scientific process, dealing with science in daily life and to psychomotor skills like recognizing and proper using laboratory materials, setting up experiment mechanisms and doing experiments.

In a study conducted with primary school students (Akgün, 2008), it was determined that the students noted the following points with respective percentiles: Laboratories are indispensible for persistency of learning (100\%), laboratories make them have new knowledge $(98,3 \%)$ laboratories attract their attention $(98,2 \%)$, laboratories attract their interest $(97,1 \%)$, laboratories support students' manual skills $(93,7 \%)$, they learnt the features of laboratory tools by means of experiments. It is obvious that such skills cannot be provided with closed ended experiments. Apparently, 
closed ended experiments bear lots of advantages such as concretizing abstract concepts, improving psychomotor skills and loosing boring classroom atmosphere. However, high order scientific process skills such as; critical thinking, setting up hypotheses, setting up experiment mechanisms based on hypotheses can only be attained with open ended or hypothesis testing experiments. In this context, it was determined that majority of the pre-service teachers preferredopen ended experiments but not hypothesis testing experiments in their lesson plans. Similarly, Feyzioğlu et al., (2011) also came up with the result that teachers, in general, did not prefer hypothesis testing experiments.

As another data gathering tool Perceptions on Laboratory Applications Scale applied in the present study. Summarizing the data coming from this scale, Table 7 shows that $12 \%-27,4 \%$ of the pre-service teachers thought that laboratory work increases the workload of teachers. 50\%-74\% of them thought that experiments improve learning skills of learners, provide consolidation for subject matter, concretizes abstract concepts, improve students' self-expression with group works, make students gain problem solving skills, help students to make associations with daily life, improve critical thinking skills, increase persistency of learning.

Based on these expressions of the pre-service teachers, it can be said that they have positive opinions towards laboratory. In order to learn by doing and living in science course, laboratory method, which is proved as one of the most effective methods of science instruction, should be effectively used. Although pre-service teachers do not perceive themselves as incompetent at laboratory safety and effective laboratory use, it is promising that they have positive opinions on laboratory use. These positive opinions are expected to improve their pedagogical skills accordingly.

\section{Suggestions}

One of the fundamental aims of Sciences course in primary school is to prepare pupils to upcoming educational stage or life itself as science literate individuals. In order to fulfill this aim it is vitally important that classroom teachers master adequate knowledge and competence on science instruction. However, as mentioned in plenty of studies in the related literature, laboratory has been still neglected. As a matter of fact, this study also found that although pre-service classroom teachers have positive opinions about using laboratory in science instruction, they perceive themselves incompetent at effective use of laboratory, laboratory safety and effective use of time in laboratory. Additionally it was determined that they did not have sufficient knowledge about types of experiment and laboratory approaches. The pre-service teachers think that the reason of this problem is that they were provided with essential theoretical information in the related courses however they did not have enough practice opportunities. Consequently, pre-service classroom teachers should be provided with wider practice opportunities in their science instruction related courses. Apart from that, we think that if academic members who deliver courses such as General Chemistry, General Physics and General Biology in initial years of university education teach these courses as laboratory oriented, this will help to improve prospective teachers' laboratory skills substantially.

\section{References}

Akcöltekin, A. (2008). Illkögrretim fen bilgisi derslerinde laboratuarların yeri ve laboratuar yeterlilikleri (Importance of laboratory and sufficient of the standards of the laboratory in science teaching in primary education). Master's thesis, Kafkas University Institute of Social Sciences, Kars.

Akgün, S. (2008).Fen bilgisi ögrretiminde laboratuar kullanımının ögrrencilerin başarılarına disiplinler arası etkisi. Master's thesis, Kafkas University Institute of Natural and Applied Sciences, Kars.

Arı, E., \& Bayram, H. (2011).The influence of constructivist approach and learning styles on achievement and science process skills in the laboratory.Primary Education Online, 10(1), 311-324.

Ayas, A., Çepni, S., \& Akdeniz, A. R. (1994). Fen bilimleri eğitiminde laboratuarın yeri ve önemi tarihsel bir bakış.Çăgdaş Ĕgitim, 204, 22-23.

Bahadır, H. (2007). Bilimsel yöntem surecine dayalı ilköğretim fen eğitiminin bilimsel süreç becerilerine, tutuma, başarlya ve kalıcllğa etkisi (The effect of elementary science education based on scientific method process on science process skills, attitude, academic achievement and retention). Master's thesis, Hacettepe University Institute of Natural and Applied Sciences, Ankara.

Başdas, E. (2007). İlköğretim fen eğitiminde basit malzemelerle yapılan fen aktivitelerinin bilimsel süreç becerilerine, akademik başarlya ve motivasyona etkisi (The effect of hands-on science learning method in the education of science in primary school on the science process skills, academic achievement and motivation). Master's thesis, Celal Bayar University Institute of Natural and Applied Sciences, Manisa.

Böyuk, U., Demir, S., \& Erol, M. (2010). Fen ve teknoloji dersi öğretmenlerinin laboratuar çalışmalarına yönelik yeterlik görüşlerinin farklı değişkenlere gore incelenmesi (Analyzing the proficiency views of science and technology teachers on laboratory studies in terms of different variables).Tubav Bilim Dergisi, 3(4), 342-349. 
Bulunuz, N., \& Ergül, R. (2001).Öğretmen adaylarının fen öğretiminde matematik bilgiyi laboratuar ölçüm araçlarını kullanmalarında kendilerine olan güvenlerini belirleme üzerine bir inceleme (An investigation on to determine the confidence of pre-service teachers using the mathematical knowledge and measuring tools in science teaching). Uludă̆ Üniversitesi Ĕ̈itim Fakültesi Dergisi, 11(1), 65-71.

Bybee, R. W. (1999). Toward an understanding of scientific literacy,(In advancing standards for science and mathematics education :views from the field). The American Association for the Advencement of Science, Washington. Retrieved 12.09.2012.from http ://ehrweb.aas.org/ehr/forum/bybee.html.

Camci, S. (2008). Bilimşenliğine katılan ve katılmayan çocukların bilim ve bilim insanlarına yönelik ilgi ve imajlarının karsilaşttrilması (Comparison of students' perceptions and images of science and scientists among whom participated the science fairs and who have not). Master's thesis, Hacettepe University Institute of Social Sciences, Ankara.

Çepni, S., Akdeniz, A. R., \& Ayas, A. (1994).Fen bilimleri eğitiminde laboratuarın yeri ve önemi-III. Çăgdaş Ĕ̆itim Dergisi, 206, 24-28.

Çepni, S., Küçük, M., \& Ayvacı, H. Ş. (2003).İlköğretim birinci kademedeki fen bilgisi programının uygulanması üzerine bir çalışma (A study on implementation of the science program at the first grade of primary schools) .Gazi Üniversitesi Ĕ̈itim Fakültesi Dergisi, 23(3),131-145.

Coştu, B., Ayas, A., Çalık, M, Ünal, S., \& Karataş, F. Ö. (2005). Determining preservice science teachers' competences in preparing solutions and in use of laboratory tools. Hacettepe University Journal of Education, 28, 65-72.

De Boer, G. E. (2000). Scientific literacy: Another look at its historical and contemporary meanings and its relationship to science education reform. Journal of Research in Science Teaching. 37 (6), 582-601. http://dx.doi.org/10.1002/1098-2736(200008)37:6<582::AID-TEA5>3.0.CO;2-L

Demir, S., Boyuk, U., \& Koc, A. (2011). Fen ve teknoloji dersi öğretmenlerinin laboratuar şartları ve kullanımına ilişkin görüşleri ile teknolojik yenilikleri izleme eğilimleri (Views of science and technology teachers on laboratory conditions and use of laboratory with their tendencies to follow technological innovations). Mersin Üniversitesi Ĕgitim Fakültesi Dergisi, 7(2), 66-79.

Demirer, V. (2009). Eğitim materyali geliştirilmesinde karma öğrenme yaklaşımının akademik başarı, bilgi transferi, tutum ve öz-yeterlilik algisina etkisi (Effect of blended learning approach on academic success, knowledge transfer, attitude, and self-efficacy perception in educational material development). Master's Thesis, Selçuk University Institute of Social Sciences, Konya.

Dindar, H., \& Yaman, S. (2002). Öğretmenlerin ilköğretim 4. ve5. sınıflarda fen bilgisi dersinde öğretim yöntemlerini kullanma durumları (A case of using teaching methods by teacher in science course at 4th and 5th class in primary school). Kastamonu Ë̆itim Dergisi, 10(1), 103-108.

Doğan, Ö. K. (2008). Biyoloji alan dersleri laboratuarlarında, öğretmen adaylarının öğrenme ve kendi değerlendirmelerinin geliştirilmesi (Promoting prospective biology teachers? learning and self-evaluation skills in biology labs). Master's Thesis, Marmara University Institute of Education Sciences, Istanbul.

Duban, N. (2008). İlköğretim fen ve teknoloji dersinin sorgulamaya dayall öğrenme yaklaşımina gore işlenmesi: bir eylem araştırmass (Conducting science and technology course through inquiry-based learning approach in primary education: An action research). Doctoral dissertation, Anadolu University Institute of Education Sciences, Eskişehir

Duban, N. (2010). Sınıf öğretmeni adaylarının fen ve teknoloji okur-yazarı bireylere ve bu bireylerin yetiştirilmesine ilişkin görüşleri (Opinions of primary school teacher candidates about science and technology literate and education these individuals). Kuramsal Ĕgitim Bilim Dergisi, 3(2), 162-174.

Ekici, G. (2002, 16-18 September). Biyoloji öğretmenlerinin laboratuar dersine yönelik tutumlarının farklı değişkenler açısından incelenmesi. Paper presented at the V. Ulusal Fen v eMatematik Eğitimi Congress, Ankara.

Erdemir, M., Aydın, A., \& Soylu, H. (1999). İlköğretim okulları 4.ve 5. sınıflarda fen bilgisi dersini yürüten öğretmenlerin karşılaştıkları sorunlar, Kastamonu Eğitim Dergisi, 7(2), 31-40.

Erdoğan, M. (2010). Grup ve gösteri deney tekniklerinin öğrencilerin bilimsel süreç becerilerine, başarılarına ve hatırda tutma düzeylerine etkileri (Effect of experiment techniques of group and demonstration to students' scientific process abilities, achievement and the ability of recalling). Master's Thesis, Selçuk University Institute of Education Sciences, Konya.

Ergul, R., Şimşekli, Y., Çalış, S., Özdilek, Z., Göçmençelebi, S., \& Şanlı, M. (2011). The effects of inquiry-based 
science teaching on elementary school students' science process skills and science attitudes. Bulgarian Journal of Science and Education, 5(1), 48-68.

Feyzioğlu, B., Demirdağ, B., Akyıldız, M., \& Altun, E. (2012).Constructing a perception scale: chemistry teachers' perceptions on laboratory applications. Journal of Turkish Science Education, 9(4), 44-63.

Feyzioğlu, B., Demirdağ, B., Ateş, A., Çobanoğlu, İ., \& Altun, E. (2011). Kimya öğretmenlerinin laboratuvar uygulamalarına yönelik algıları: İzmir ili örneği (Chemistry teachers' perceptions on laboratory applications: İzmir sample). Kuram ve Uygulamada Ĕgitim Bilimleri, 11(2), 1005-1029.

Gallagher, J. J. (1987). A summary of research in science education. Science Education, 71, 277-284.

Gencturk, H. A., \& Turkmen, L. (2007). İlköğretim 4.sınıf fen bilgisi dersinde sorgulama yöntemi ve etkinliği üzerine bir çalışma (A study of effectiveness and application of inquiry method in a 4th grade science course). Gazi Ĕgitim Fakültesi Dergisi, 27(1), 277-292.

Gömleksiz, M. N., Ülkü, K. A., \& Biçer, S. (2010). Sınıf öğretmenlerinin fen ve teknoloji dersini yürütmeye yönelik özyeterlikleri (Self-efficacy level of classroom teachers towards science and technology teaching).C.Ü. Sosyal Bilimler Dergisi, 34(2), 21-30.

Güneş, M. H., Şener, N., Topal Germi, N., \& Can, N. (2013). Fen ve teknoloji dersinde laboratuar kullanımına yönelik öğretmen ve öğrenci değerlendirmeleri (Teacher and student assessments regarding to use of science and technology laboratory). DicleÜniversitesi Ziya Gökalp Eğitim Fakültesi Dergisi, 20, 1-11.

Güneş, T., \& Demir, S. (2007). İlköğretim müfredatındaki hayat bilgisi derslerinin, öğrencileri fen öğrenmeye hazırlamadaki etkileri (Effect of life and social science courses presented in primary school curriculum on preparation of students for science learning). Hacettepe University Journal of Education, 33,169-180.

Güngör, S. H. (2008). Kimya eğitiminde sorgulamaya dayalı öğrenci deneylerinin geliştirilmesi ve sonuçlarının tartışlmasl (Developing inquiry based student experiments in the chemistry education and discussing results). Doctoral dissertation, Anadolu University Institute of Natural and Applied Sciences, Ankara.

Gürdal, A. (1992). İlköğretim okullarında fen bilgisinin önemi. Hacettepe Üniversitesi Eğitim Fakültesi Dergisi ,8, 185-189

Harman, G. (2012). Sınıf öğretmeni adaylarının fen ve teknoloji öğretiminde kullanılan laboratuar araç gereçleri ile ilgili bilgilerinin incelenmesi. Journal of Educational and Instructional Studies in the World, 2(1), 122-127.

Hofstein, A., \& Lunetta, V. N. (2004). The laboratory in science education: foundation for the 21 st century. Science Education, 88, 28-54. http://dx.doi.org/10.1002/sce.10106

Karaer, H. (2007). Sınıf öğretmeni adaylarının madde konusundaki bazı kavramları anlaşılma düzeyleri ile kavram yanılgılarının belirlenmesi ve bazı değişkenler açısından değerlendirilmesi (Examination of student teachers' levels of understanding and misconceptions of some concepts about substance and determination regarding to some variables). Kastamonu Eğitim Dergisi, 15(1), 199-210.

Konur, K., \& Ayas, A. (2008). Sınıf öğretmeni adaylarının bazı kimya kavramlarını anlama seviyeleri (The level of understanding of class teacher candidates" some chemistry concepts). Kastamonu Üniversitesi Ĕgitim Fakültesi Dergisi, 16(1), 83-90.

Küçükyılmaz, E. A., \& Duban, N. (2006). Sınıf öğretmeni adaylarının fen öğretimi öz-yeterlik inançlarının artırılabilmesi için alınacak önlemlere ilişkin görüşleri (The opinions of primary teacher candidates on taking measures to increase science teaching self-efficacy beliefs).Yüzüncü Yll Üniversitesi Eğitim Fakültesi Dergisi, 3(2), $1-23$.

Laipply, R. S. (2004). A case study of self-efficacy and attitudes toward science in an inquiry based biology laboratory. Doctoral dissertation, Akron University.

Meriç, G., \& Ersoy, E. (2007).Sınıf öğretmenliği son sınıf öğrencilerinin fen öğretiminde yeterlilik düzeyi algıları (The perceptions of the fourth class students of classroom teachers education program at science instruction related to the proficiency levels). Mersin Üniversitesi Ë̆itim Fakültesi Dergisi, 3(1), 51-62.

Özdemir, M., \& Azar, A. (2004, 6-9 July).Fen öğretmenlerinin laboratuar derslerine yönelik tutumları. Paper presented at the XIII. Ulusal Eğitim Bilimleri Kurultayı, Malatya.

Sarı, M. (2011, 27-29 April). İlköğretim fen ve teknoloji derslerinin öğretiminde laboratuarın yeri ve basit araç gereçlerle yapılan fen deneyleri konusunda ögretmen adaylarının görüşlerinin değerlendirilmesi (The importance of laboratory courses in science and technology teaching in primary education and the ideas of simple tools and 
instruments to evaluate teacher candidates on science experiments). Paper presented at the 2 nd International Conference on New Trends in Education and Their Implications, Antalya.

Tekin, S., Uluçınar, S. Ş., \& Karamustafaoğlu, S. (2012). Sınıf öğretmeni adaylarının Fen Bilgisi Laboratuar Uygulamaları - 1 dersi kazanımlarının kimya deneyleri açısından incelenmesi (Examining the science Laboratory Applications - 1 skills of classroom teachers depending on chemistry experiments). Pamukkale Üniversitesi Eğitim Fakültesi Dergisi, 31(1), 163-174.

Tobin K. G. (1990), Research on science laboratory activities; in pursuit of better questions and answers to improve learning. School Science and Mathematics, 90, 403-418. http://dx.doi.org/10.1111/j.1949-8594.1990.tb17229.x

Toraman, S., \& Alcı, B. (2013). Fen ve teknoloji öğretmenlerinin yenilenen fen bilimleri dersi öğretim programına ilişkin görüşleri (Science and technology teachers' opinions about renewed science lesson curriculum). Ekev Akademi Dergisi, 56, 11-22.

Turkish Ministry of National Education, (2005).Science and technology textbook Curriculum for 4th and 5th grade.(5th Ed.). Ministry of National Education, Ankara: States Books.

Turkish Ministry of National Education, (2013). Science textbook for 3,4,5,6,7 and 8th grade. Ministry of National Education, Ankara: States Books.

Yaşar, Ş., \& Duban, N. (2009). Sorgulamaya dayalı öğrenme yaklaşımına yönelik öğrenci görüşleri. İlköğretim Online, $8(2), 457-475$.

Yıldırım, N., \& Akgün, Ö. (2015). İlkokul 3.sınıf öğretmenlerinin yenilenen fen bilimleri dersine ilişkin görüşleri (Opinions of the third grade classroom teachers about the altered science course). Klrşehir Eğitim Fakültesi Dergisi, 16(2), 199-218.

Yıldırım, N., \& Birinci, K. K. (2014). Fen bilgisi öğretmen adaylarının kimya kavramlarını günlük hayatla ilişkilendirebilmelerine yönelik gelişimsel biraraştırma (A developmental research for science teachers candidates' associating chemistry concepts with everyday life). The Journal of Academic Social Science Studies, 30, 305-323. http://dx.doi.org/10.9761/JASSS2608

Yıldırım, N., \& Güneş, L. (2012, 24-26 May).Sinıf öğretmen adaylarının kimya kavramlarını günlük hayatlarlyla ilişskilendirebilmelerine yönelik becerilerinin belirlenmesi. Paper presented at the 11. Ulusal Sınıf Öğretmenliği Eğitimi Symposium, Recep Tayyip Erdoğan University, Rize.

Yıldırım, N., Kurt, S., \& Güneş, L. (2014). Effects of inquiry based learning approaches on scientific process skills and academic achievement of pre-service classroom teachers. International Journal of Academic Research, Part B. Humanities and Social Sciences, 6(6), 46-54.

This work is licensed under a Creative Commons Attribution 3.0 License. 